Manuscript received March 20, 2016; accepted for publication November 2, 2016; published online December 22, 2017.

${ }^{1}$ Department of Civil Engineering, Payame Noor University, P.O. Box 19395-4697, Tehran, Iran, e-mail: kazemian.s@pnum.ac.ir

2 Department of Civil Engineering, Payame Noor University, P.O. Box 19395-4697, Tehran, Iran, e-mail: ghareh_soheil@pnu.ac.ir
S. Kazemian ${ }^{1}$ and S. Ghareh ${ }^{2}$

\section{Effects of Cement, Different Bentonite, and Aggregates on Plastic Concrete in Besh-Ghardash Dam, Iran}

\section{Reference}

Kazemian, S. and Ghareh, S., "Effects of Cement, Different Bentonite, and Aggregates on Plastic Concrete in Besh-Ghardash Dam, Iran," Journal of Testing and Evaluation, Vol. 45, No. 1, 2017, pp. 242-248, http://dx.doi.org/10.1520/JTE20160161. ISSN 0090-3973

\section{ABSTRACT}

Besh-Ghardash Dam is located 5 km from Bojnourd city in North Khorasan Province, Iran. This research investigated the use of a plastic concrete. Because of a lack of specified standards for such materials, there is a serious need to evaluate effects from the amount and the quality of concrete aggregates (fine and coarse gravel and sand), cement, water, and bentonite on mechanical properties. This study looked at the effect of the ratio of mixture proportions and cement, as well as the materials' quality, such as the type of bentonite on compressive strength, modulus of elasticity, and permeability of plastic concrete. The results showed that by decreasing the ratio of term activity in bentonite reduced compressive strength, because of an increase in free water when other components were held stable. The effect of the cement has a direct effect on elastic modulus, as well as the compressibility of plastic concretes. The results showed that there is a direct effect of the cement on the permeability of such plastic concrete.

\section{Keywords}

aggregate, plastic concrete, compressive strength, permeability, modulus elasticity

\section{Introduction}

Besh-Ghardash dam is situated on Besh-Ghardash road $5 \mathrm{~km}$ from Bojnourd City in North Khorasan Province, Iran (Fig. 1). Plastic concrete is applied in many structures, such as in a cutoff wall, a 
FIG. 1 (a) Location of Besh-Ghardash in Iran and (b) Besh-Ghardash dam (under construction).
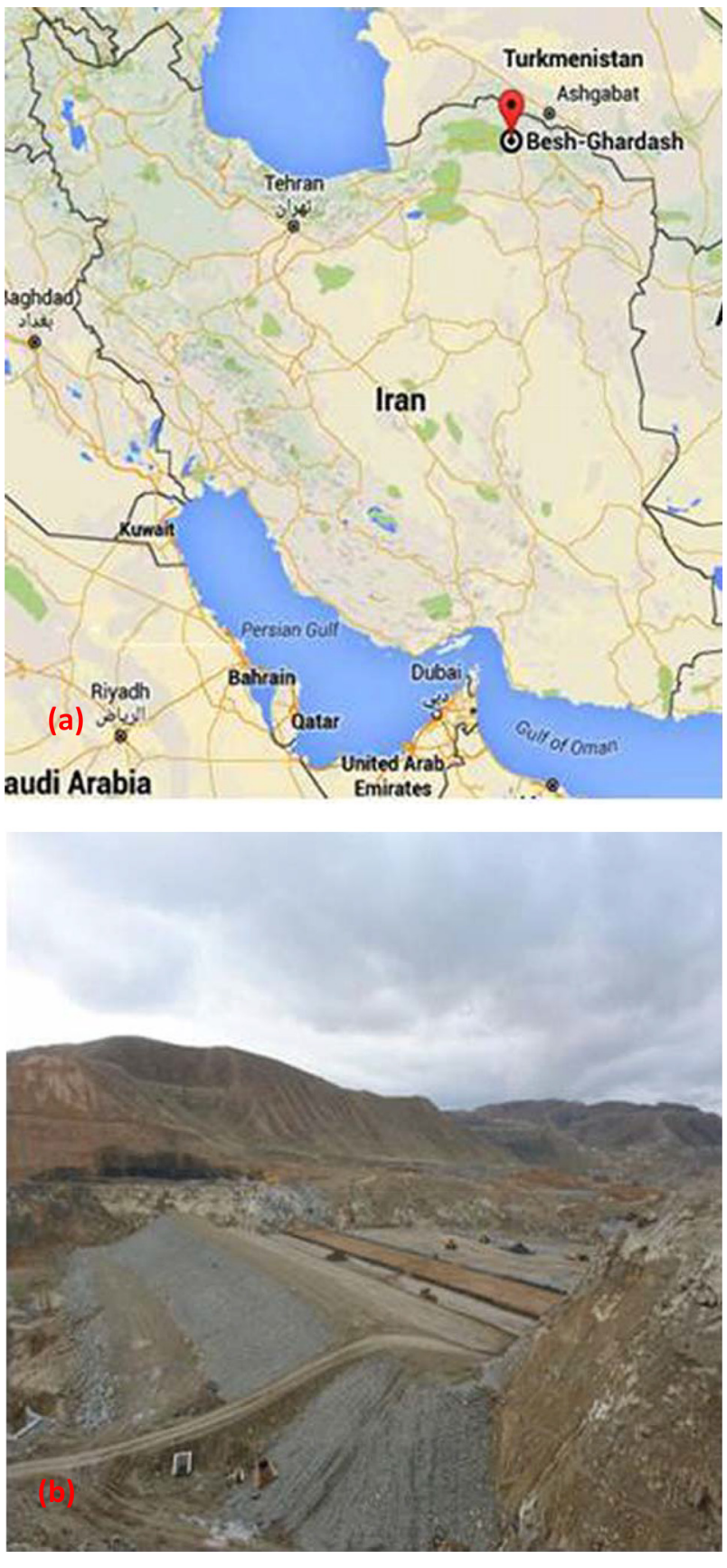

cutoff curtain, in grouting and vibration damping walls to prevent the spread of pollutants from industrial factories in underground water, to control seepage under the dams' foundation, and in building cutoff walls $[1,2]$. The main application is for sealing the foundation of earth and gravel dams [3]. There are various factors affecting the choice of materials and plastic concrete mix design, such as the rate of permeability of the desired location, site conditions, and access to materials at the site, along with economic and administrative considerations $[4,5]$.

Plastic concrete is made with bentonite slurry, where the role of bentonite slurry is to maintain the suspended cement, sand, and gravel particles during operations. It also increases plasticity and reduces the rate of permeability. More water is used in a mix design to provide maximum flexibility in plastic concrete. This can cause instability in fresh concrete (separation) [6]. Jefferis [7] showed that increasing the amount of bentonite reduces compressive strength and the hydraulic conductivity of plastic concrete.

Cement is also a factor in the bonding of components in plastic concrete. If a low amount of bentonite is used in the mix design, a part of the cement will be deposited. The design will be uneconomical if the amount of bentonite is high and it is difficult to work with the cement. Therefore, a low amount of cement is considered an appropriate mix design compared to no sedimentation $[8,9]$.

Aggregates form about $60 \%-80 \%$ of the total volume of plastic concrete. This amount of sand and gravel prevents a constant sticking of particles and thereby reduces their deformation. Gradation curves must be continuous and the percentage of fine grains must be low. If the colloidal fine grain material is high, then the amount of bentonite should be reduced [10].

Zolnoor and Ahmadi [11], Hajnal et al. [12], and Xanthakos [13] emphasized that the use of diaphragm walls with plastic concrete is increasing in dams and also in underground dams. This is because of the development of industry, population growth, and because of a lack of water surface storage.

There has been previous research into changes in the physical properties of plastic concrete because of its components. However, the lack of specific standards is a very serious concern $[14,15]$. Eslamian [16] showed that using ordinary concrete codes are not suitable and the results are not correct because of the high flexibility of plastic concrete. This paper investigated the effect of the ratio of mixing materials and cement as well as the material quality such as the type of bentonite on compressive strength, modulus elasticity and permeability of plastic concrete.

TABLE 1 Distribution table of coarse aggregates-coarse gravel.

\begin{tabular}{lcccccccccccccc}
\hline Sieve No. & $11 / 2^{\prime \prime}$ & $1^{\prime \prime}$ & $3 / 4^{\prime \prime}$ & $1 / 2^{\prime \prime}$ & $3 / 8^{\prime \prime}$ & 4 & 8 & 16 & 30 & 50 & 100 & 200 \\
\hline Pass \% & 100 & 100 & 81.98 & 3.46 & 1.15 & 0.5 & 0.49 & 0.47 & 0.44 & 0.44 & 0.43 & 0.42 \\
\hline
\end{tabular}


TABLE 2 Distribution table of coarse aggregates-fine gravel.

\begin{tabular}{lccccccccccccccc}
\hline Sieve No. & $11 / 2^{\prime \prime}$ & $1^{\prime \prime}$ & $3 / 4^{\prime \prime}$ & $1 / 2^{\prime \prime}$ & $3 / 8^{\prime \prime}$ & 4 & 8 & 16 & 30 & 50 & 100 & 200 \\
\hline Pass \% & 100.00 & 100 & 100 & 88.26 & 76.97 & 3.31 & 2.61 & 1.9 & 1.4 & 1.11 & 1 & 0.96 \\
\hline
\end{tabular}

\section{Materials and Method}

\section{MATERIALS}

\section{Aggregates}

Tables 1-3 are distribution curves of the aggregates used in the desired design in this research with acceptable ranges suggested based on various standards.

\section{Cement}

Type II cement was used in plastic concrete mix designs from a Bojnourd cement factory. Physical and chemical tests for determining the type of cement are provided in Table 4.

\section{Bentonite}

There are no standards for the technical characteristics of bentonite applied in plastic concrete. However, tests indicated that its' plasticity has a significant impact on plastic concrete mechanical properties. Two types of bentonite were applied in this research and their specifics are provided in Table 5. Tests were based on ASTM D4318-05 [18].

\section{METHOD FOR DETERMINING PLASTIC CONCRETE MECHANICAL PROPERTIES}

A special device was used to measure the strength and deformation of plastic concrete and to determine the mechanical properties of this concrete (compressive strength and elasticity modulus). This device (Fig. 2) has a digital display and can be connected to a computer to draw stress-strain and forcemovement curves. It has also an adjustable loading speed from $0.01 \mathrm{~mm} / \mathrm{min}$ to $3 \mathrm{~mm} / \mathrm{min}$.

\section{Determining Compressive Strength of Plastic Concrete}

If the compressive strength of plastic concrete is high, then the applied forces do not have a desirable deformation and will crack and be broken from low strains. Thus, the aim is to obtain a desired strength. The International Committee on Large Dams [19] suggested that the modulus of elasticity of plastic concrete should be 4 to 5 times more than the modulus of the surrounding soil. Within the test, the loading speed in scrip soils (more than typical soils and less than typical concrete) gives better results in terms of strength and modulus of elasticity. However, considering the suggestions of ASTM C469 [27] and ASTM D2166 [28], the speed of the compression testing machine in this study was considered at $0.15 \mathrm{~mm} / \mathrm{min}$. To implement the test, the sample surface was initially capped to prevent stress concentration and a non-uniform distribution on the samples. Because of the low strength of plastic concrete, very fine plasters (passed from a No. 300 sieve) were used for capping. The effect of capping with different materials was investigated by Zafari et al. [20]. The results showed that plaster is better than cement for distributing stress on sample surfaces.

The device was then turned on after putting the capped sample under the device jack in a vertical direction and in contact with loading pages. Information about force and deflection was stored automatically by the recording device throughout. In this way, a stress-strain diagram was drawn for a sample. The maximum measured force until failure of the sample was recorded and compressive strength was determined based on the surface of a plastic concrete sample.

\section{Determining Elasticity Modulus of Plastic Concrete}

Elasticity modulus does not have a proper meaning and a constant value, primarily because soil deformation is because of the relative movement of particles and different stress levels. Thus, soil behavior is different against the applied force $[16,20]$. Thus, it is preferable to use the module or deformation coefficient. This coefficient describes the relationship between stresses and deformations. There are two general methods to calculate the linear stress module [21]:

- The tangent modulus is based on the slope of the tangent at any point on the curve and usually the tangent of the first part of the curve is called the initial tangent modulus ASTM D2166.

- Secant modulus is based on the line slope between two points; usually the two points are in the range of service stress ASTM C469.

The modulus of elasticity cannot be obtained via the ASTM C469 method because plastic concrete behavior differs from ordinary concrete. This method is based on the fact that the behavior of ordinary concrete is up to $40 \%$ of the ultimate strength of the linear elastic and concrete modulus of elasticity, which is defined based on this behavior. Whereas, in plastic

TABLE 3 Distribution table of fine aggregates-sand.

\begin{tabular}{|c|c|c|c|c|c|c|c|c|c|c|c|c|}
\hline Sieve No. & $11 / 2^{\prime \prime}$ & $1^{\prime \prime}$ & $3 / 4^{\prime \prime}$ & $1 / 2^{\prime \prime}$ & $3 / 8^{\prime \prime}$ & 4 & 8 & 16 & 30 & 50 & 100 & 200 \\
\hline Pass \% & 100 & 100 & 100 & 100 & 100 & 91.87 & 58.99 & 34.54 & 15.73 & 10.84 & 6.4 & 4.67 \\
\hline
\end{tabular}


TABLE 4 Cement tests.

\begin{tabular}{lcc}
\hline Component & $\begin{array}{c}\text { Cement } \\
\text { Specification }\end{array}$ & $\begin{array}{c}\text { Standard Specification, } \\
\text { ISIRI No. 389 [17] }\end{array}$ \\
\hline $\mathrm{SiO}_{2}$ & 21.49 & $>20$ \\
$\mathrm{Al}_{2} \mathrm{O}_{3}$ & 4.37 & $<6$ \\
$\mathrm{Fe}_{2} \mathrm{O}_{3}$ & 3.57 & $<6$ \\
$\mathrm{CaO}$ & 64.17 & - \\
$\mathrm{MgO}$ & 2.81 & $<5$ \\
$\mathrm{SO}_{3}$ & 2.18 & $<3$ \\
Loss on ignition & 0.89 & $<3$ \\
\hline
\end{tabular}

concrete, not only is this behavior not linear, it is also not elastic. As such, the definition of elasticity modulus of plastic concrete is not the same as ordinary concrete. Additionally, the loading speed is so high that an operator is unable to read the stress-strain values [16].

In this research, the elasticity modulus of plastic concrete was calculated by drawing a diagram based on the standard from ASTM D2166 while considering the slope of the curve in the linear region [10]:

$$
E=\left(\sigma_{b}-\sigma_{a}\right) /\left(\varepsilon_{b}-\varepsilon_{a}\right)
$$

where:

$\sigma_{b}=$ maximum stress in the linear part of the stress-strain curve,

$\sigma_{a}=$ minimum stress in the linear part of the stress-strain curve,

$\varepsilon_{b}=$ maximum strain in the linear part of the stress-strain curve, and

$\varepsilon_{a}=$ minimum strain in the linear part of the stress-strain curve.

\section{Determining Plastic Concrete Marsh}

Marsh funnel (viscosity) or marsh density measures the time necessary to pass a certain volume of liquid thru a funnel marsh with dimensions and volume that are determined. The dimensions of the outlet hole are also defined. The marsh density of bentonite slurry is done in a basin before concrete production. A suitable range of marsh density is usually between 40 and $50 \mathrm{~s}$ after at least $72 \mathrm{~h}$ soaking of bentonite in water to finish the absorption [22].

\section{Determining Plastic Concrete Permeability}

This research found the permeability of plastic concrete based on DIN 1048-5 [23]. The specimen was investigated after 3 days

TABLE 5 Atterberg limits of two types of bentonite.

\begin{tabular}{llll}
\hline Bentonite No. & LL (\%) & PL (\%) & PI (\%) \\
\hline 1 & 532.9 & 68.21 & 464 \\
2 & 387 & 47 & 340 \\
\hline
\end{tabular}

FIG. 2 Measurement apparatus for compressive strength and deformation of plastic concrete.

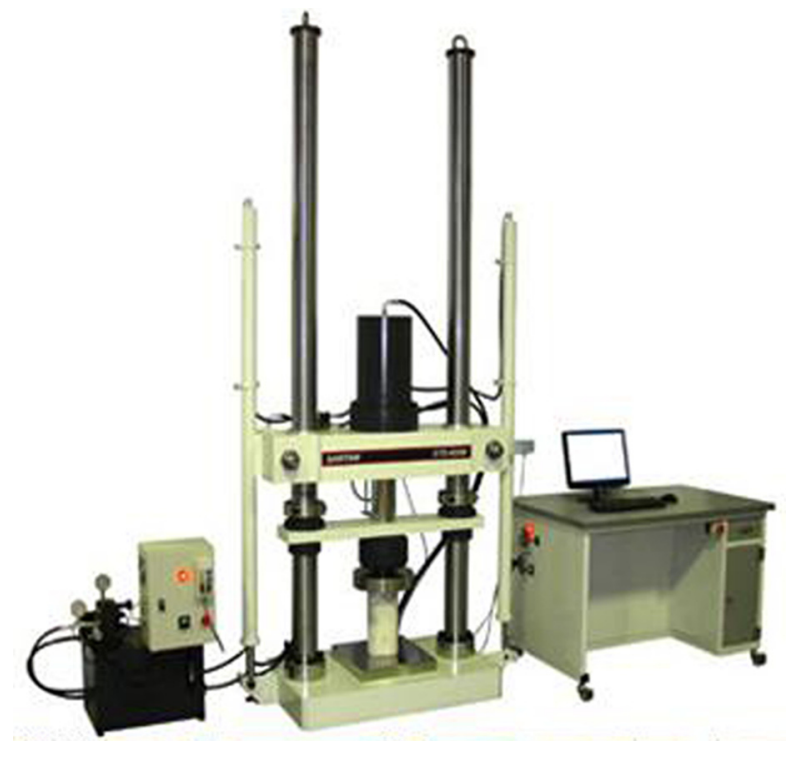

under a pressure $0.5 \mathrm{MPa}$, where the maximum depth of penetration of water was measured based on a Valenta equation and plastic concrete was calculated based on Eq 2 [15]:

$$
K=\left(v \cdot d^{2}\right) /(2 t h)
$$

where:

$K=$ plastic concrete permeability $(\mathrm{cm} / \mathrm{s})$,

$v=$ voids in the specimen (without any measurement, this is suggested as 0.1),

$d=$ penetration depth $(\mathrm{cm})$,

$t=$ time of the test (s), and

$h=$ head of water in the test $(\mathrm{cm})$.

\section{Determine Optimal Material Mix Ratios}

\section{(Mixture Proportions)}

Extensive field surveys were done in this research. Approximately 20 initial mix designs were chosen to investigate the effect of different mixture proportions and the compressive strength of elasticity modulus (these tests were conducted on 28-day cylindrical samples with dimensions of $15 \times 30 \mathrm{~cm}^{2}$ ). Table 6 provides a summary for different mixture proportions:

\section{Results and Discussion}

\section{EFFECTS OF CEMENT ON COMPRESSIVE STRENGTH AND ELASTICITY MODULUS OF PLASTIC CONCRETE}

This study investigated the effects of cement on compressive strength and elasticity modulus of plastic concrete. This was done by fixing the ratio of aggregates and a fixed type of bentonite. Changes in the ratio of cement in the design mix were 
TABLE 6 Summary of plastic concrete mix designs.

\begin{tabular}{|c|c|c|c|c|c|c|c|}
\hline \multicolumn{2}{|l|}{ Gels } & \multicolumn{5}{|c|}{ Aggregates } & \multirow[b]{2}{*}{$\begin{array}{l}\text { Design } \\
\text { No. }\end{array}$} \\
\hline $\begin{array}{l}\text { Marsh } \\
(\mathrm{Sec})\end{array}$ & $\begin{array}{l}\text { Ratio of Water } \\
\text { to Bentonite }\end{array}$ & $\begin{array}{l}\text { Ratio of Coarse Aggregates } \\
\text { per Fine Aggregates (Sand) }\end{array}$ & $\begin{array}{c}\text { Coarse } \\
\text { Gravel (kg) }\end{array}$ & $\begin{array}{c}\text { Fine } \\
\text { Gravel }(\mathrm{kg})\end{array}$ & $\begin{array}{l}\text { Sand } \\
(\mathrm{kg})\end{array}$ & $\begin{array}{l}\text { Cement } \\
(\mathrm{kg})\end{array}$ & \\
\hline \multicolumn{8}{|c|}{ Mix design with bentonite No. 1} \\
\hline 52 & $17: 1$ & 0.79 & 339 & 244 & 732 & 90 & 1 \\
\hline 54 & $17: 1$ & 0.56 & 135 & 330 & 835 & 100 & 2 \\
\hline 52 & $17: 1$ & 0.80 & 339 & 244 & 732 & 120 & 3 \\
\hline 54 & $17: 1$ & 0.56 & 327 & 164 & 750 & 130 & 4 \\
\hline 54 & $17: 1$ & 0.65 & 135 & 330 & 835 & 130 & 5 \\
\hline 54 & $17: 1$ & 0.80 & 382 & 468 & 750 & 130 & 6 \\
\hline 54 & $17: 1$ & 1.13 & 339 & 244 & 732 & 130 & 7 \\
\hline 53 & $17: 1$ & 0.80 & 244 & 341 & 732 & 140 & 8 \\
\hline 55 & $17: 1$ & 0.56 & 135 & 330 & 835 & 150 & 9 \\
\hline 55 & $17: 1$ & 0.56 & 339 & 244 & 732 & 150 & 10 \\
\hline 50 & $17: 1$ & 0.67 & 238 & 287 & 784 & 150 & 11 \\
\hline 54 & $17: 1$ & 0.80 & 135 & 330 & 835 & 150 & 12 \\
\hline 55 & $17: 1$ & 1.13 & 382 & 468 & 750 & 150 & 13 \\
\hline 50 & $17: 1$ & 0.67 & 238 & 287 & 784 & 200 & 14 \\
\hline 50 & $17: 1$ & 0.56 & 135 & 330 & 835 & 200 & 15 \\
\hline \multicolumn{8}{|c|}{ Mix design with bentonite No. $2^{*}$} \\
\hline 38 & $17: 1$ & 0.80 & 339 & 244 & 732 & 120 & $16^{*}$ \\
\hline 37 & $17: 1$ & 0.80 & 339 & 244 & 732 & 130 & $17^{*}$ \\
\hline 38 & $17: 1$ & 0.80 & 339 & 244 & 732 & 150 & $18^{*}$ \\
\hline
\end{tabular}

also considered. Design mix 1, 3, 7, and 10 were comprised of $90 \mathrm{~kg}, 120 \mathrm{~kg}, 130 \mathrm{~kg}$, and $150 \mathrm{~kg}$ of cement, respectively (the remaining components were fixed). The stress-strain diagrams of each design mix are shown in Table 7.

The compressive strength of these concrete samples increased from $3.45 \mathrm{~kg} / \mathrm{cm}^{2}$ to $14.38 \mathrm{~kg} / \mathrm{cm}^{2}$ after 28 days. This was because of chemical reactions for hydration between water and cement and also carbonation reactions caused by the presence of cement, bentonite, and water that acted in the mix. These findings were in agreement with Zafari et al. [20].

Fig. 3 shows that according to the linear slope of the diagrams and the above-mentioned discussion, components of Nos. 1, 3, 7, and 10 have an elasticity modulus of 2783, 4241, 6910 , and $11,736 \mathrm{~kg} / \mathrm{cm}^{2}$, respectively. Moreover, the relative increase of cement to $60 \%$ will increase the modulus of elasticity by up to five times. This reflects the crisp of concrete and shows the high influence of cement on this property (Table 7).

TABLE 7 Effect of cement on compressive and modulus elasticity of plastic concrete.

\begin{tabular}{lccc}
\hline Sample No. & Cement $(\mathrm{kg})$ & $f c\left(\mathrm{~kg} / \mathrm{cm}^{2}\right)$ & $E\left(\mathrm{~kg} / \mathrm{cm}^{2}\right)$ \\
\hline 1 & 90 & 3.4 & 2783 \\
3 & 120 & 6.0 & 4241 \\
7 & 130 & 8.3 & 6910 \\
10 & 150 & 14.5 & 11736 \\
\hline
\end{tabular}

FIG. 3 Modulus of elasticity of mixture No. 10

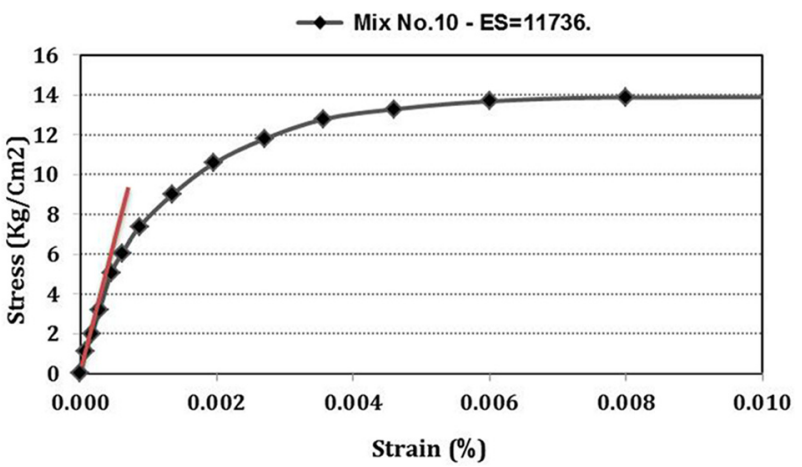

FIG. 4 Effect of different ratios of coarse aggregates to fine aggregates (sand) on compressive strength of plastic concrete.

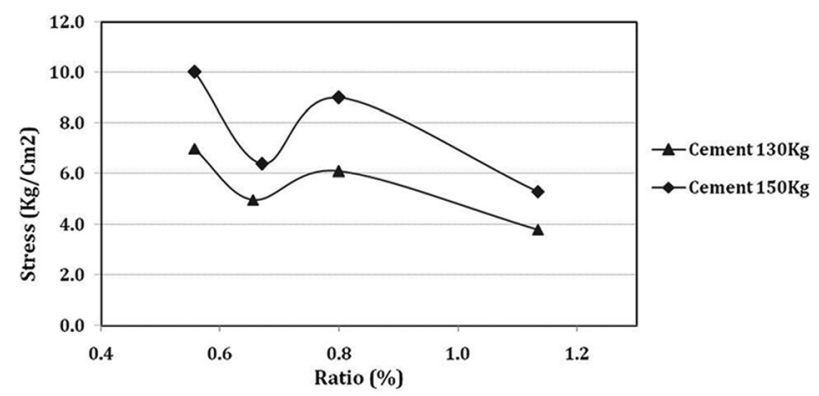


FIG. 5 Effect of marsh on compressive strength of plastic concrete.

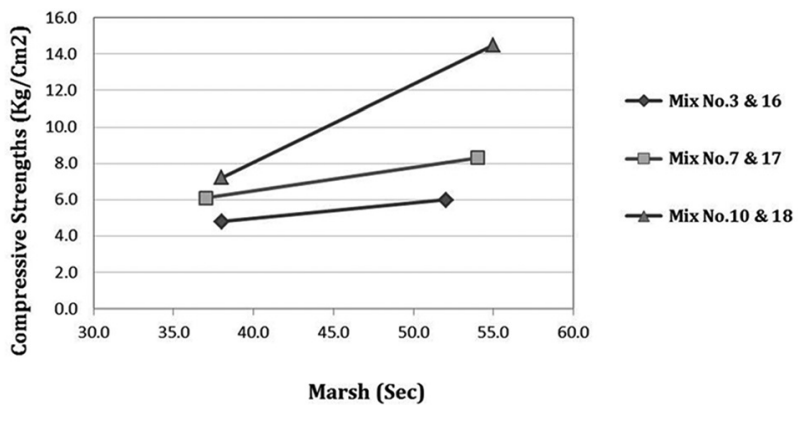

Increasing this parameter by too much in plastic concrete would create an unacceptable conflict in the behavior between concrete and the surrounding soil. The above findings agree well with those from Zafari et al. [20].

\section{EFFECT OF THE AGGREGATE ON COMPRESSIVE STRENGTH OF PLASTIC CONCRETE}

Design Nos. 4, 5, 6, and 7 were considered in terms of the ratios of coarse aggregates (fine gravel plus coarse gravel) per fine aggregates (sand) with $130 \mathrm{~kg}$ of cement. Design Nos. 9, $10,11,12$, and 13 were changed per the mentioned ratios and considered for $150 \mathrm{~kg}$ of cement. Fig. 4 indicates changes in stress. Sinusoidal and irregular changes of different values indicate that there was no direct effect of this parameter in terms of the compressive strength of concrete. It can be concluded that changing the ratios of fine aggregates to coarse aggregates or vice versa depending on the ratio rate can reduce or increase the compressive strength of plastic concrete. In total, the continuity of aggregate materials can increase compressive strength [24]. In other words, uncertain changes during an increasing process of the ratio of coarse to fine indicates the lack of a certain relation in the compressive strength of plastic concrete. There is an increase in strength by reducing the porosity inside the concrete environment. The point at which this type of aggregate has reached the best strength is at a ratio of 0.55 (reflected in design Nos. 4 and 9, with compressive strengths of 7 and $10 \mathrm{~kg} / \mathrm{cm}^{2}$, respectively). This ratio showed the highest strength for two different designs. The trends for both sets of concrete in terms of strength are drawn in the form of two graphs in Fig. 4. The results confirm the above discussion.

\section{EFFECT OF MARSH ON COMPRESSIVE STRENGTH OF PLASTIC CONCRETE}

Marsh funnel (viscosity) is measured based on the previous discussion and was addressed in mixtures Nos. 3, 16, 7, 17, 10, and 18. In these mixtures, the amount of all components are the same, except for the amount of their marsh as determined by the type of bentonite. In mixture Nos. 3, 7, and 10, the marsh of mixtures was between 50 and $55 \mathrm{~s}$. Meanwhile, for mixture Nos. 16,17 , and 18, it was 37-38 s. Fig. 5 shows the effect of marsh on the compressive strength of plastic concrete. The strength in mix No. 16 had a marsh of $38 \mathrm{~s}$, and the compressive strength increased from 4.8 to $6 \mathrm{~kg} / \mathrm{cm}^{2}$ in mixture 3 with a marsh 52 of s. This was because of an increase in water to decrease the marsh, through a reduction in the hydration of the mixtures (Fig. 5).

Parameter A (term activity) was defined as the activity in clay soils to explain the absorption of water with clay. In this situation, this parameter indicates the clay behavior and the power of hydration on the clay $[25,26]$. For the bentonites used in this report, the value of the A parameter was reduced from 7.1 to 5.4 , reflecting a reduction of hydration in bentonite No. 2 compared to bentonite No. 1 or presence of excess free water on the inside of concrete mixtures with bentonite No. 2 .

\section{EFFECT OF CEMENT ON PERMEABILITY OF PLASTIC CONCRETE}

The effect of cement on the permeability of plastic concrete was investigated in mixture Nos. 1, 3, 7, and 10. The cement in mix No. 1 increased from $90 \mathrm{~kg}$ to $150 \mathrm{~kg}$ in No. 10. Permeability decreased from $1.68 \mathrm{E}-07$ to $8.36 \mathrm{E}-8 \mathrm{~cm} / \mathrm{s}$ respectively. This was because of a decrease of voids in the mixture caused by the increase in cement (Table 8).

\section{Summary}

This manuscript presented our findings for different mixture proportions of plastic concrete and the impacts of these percentages on various mechanical properties. The results are as follows:

1. Comparative results show that compressive strength and the elasticity modulus of plastic concrete will increase with an increase of cement with a fixed amount of water and other components.

TABLE 8 Effect of cement on plastic concrete permeability.

\begin{tabular}{|c|c|c|c|c|c|}
\hline Sample No. & Day of Test & Pressure (Bar) & Penetration Height $(\mathrm{cm})$ & Voids Ratio & $K(\mathrm{~cm} / \mathrm{s})$ \\
\hline 1 & 28 & 5.0 & 3.8 & 0.10 & $1.68 \mathrm{E}-07$ \\
\hline 3 & 28 & 5.0 & 4.5 & 0.10 & $8.0 \mathrm{E}-07$ \\
\hline 7 & 28 & 5.0 & 6.6 & 0.10 & 7.81E-8 \\
\hline 10 & 28 & 5.0 & 6.9 & 0.10 & $8.36 \mathrm{E}-8$ \\
\hline
\end{tabular}


2. Changing the ratios of fine and coarse aggregates can lead to a reduction or increase in the compressive strength of plastic concrete depending on the rate of ratios. There is not a fixed ratio or uniform trend in terms of plastic concrete strength.

3. Marsh has direct effect on the compressive strength of plastic concretes. An increase in marsh will result in an increase in compressive strength.

4. An increase in the amount of cement decreased the permeability of plastic concrete. This was because of a decrease of voids in the mixtures.

\section{References}

[1] Hoshyari, I. and Rafaat pour, A., "The Comparison Behavior of Plastic Concrete in Axial and Triaxial Conditions," 1st National Civil Engineering Congress, Tehran, Iran, 13-17 May 2004 (in Persian).

[2] Repair, Evaluation, Maintenance and Rehabilitation (REMR), "Design Procedure for Plastic Concrete Cut Off Walls," Technical Note GT-SR-1.3, 1992.

[3] Sourosh, A. and Espendar, K., "Laboratory Investigation of Plastic Concrete Behavior Under Confined Pressure," 3rd International Symposium of Geotechnical Engineering and Soil Mechanics, Tehran, Iran, 9-12 December 2002 (in Persian).

[4] Mehta, P. and Monteiro, P., Concrete: Structure, Properties, and Materials, Prentice Hall, Englewood Cliffs, NJ, 1993.

[5] Ryan, C. R., "Slurry Cutoff Walls: Applications in the Control of Hazardous Wastes," Hydraulic Barriers in Soil and Rock, ASTM STP874, A. I. Johnson, R. K. Frobel, N. J. Cavalli, and C. B. Pettersson, Eds., ASTM International, West Conshohocken, PA, 1985, pp. 9-23.

[6] Brenner, P., Roshanzamir, I., and Abed, J., "Design of Cofferdams," Technical Report, Ostour Dam \& Hydropower Plant Project, Mianeh, Iran, 2003.

[7] Jefferis, S. A., "Bentonite-Cement Slurries for Hydraulic Cut Offs," Proceedings of the 10th International Conference on Soil Mechanics and Foundation Engineering, A.A. Balkema, Rotterdam, The Netherlands, June 15-19 1981, pp. 435-440.

[8] Nielson, M. P. and Hoang, L. C., Limit Analysis and Concrete Plasticity, 3rd ed., Taylor and Francis, London, 2011, 789 pp.

[9] Pashazadeh, A., Kiakhosravi, M., and Ganjian, V., "Estimate Appropriate Plastic Concrete Mix Design of Cut Off Walls to Control Water Seepage Under the Earth Dam Foundation," Water Sci. Res. Quart., Vol. 1, No. 1, 2009, pp. 63-68 (in Persian).

[10] Thomas, W. K., Joseph, L. K., and Edward, B. P., 1991, "Plastic Concrete Cut Off Walls for Earth Dams," Technical Report, U.S. Army Engineer Waterways Experiment Station, University of Michigan, Ann Arbor, MI.

[11] Zolnoor, A. and Ahmadi, M. N., "The Method to Design and Execution of Underground Dams With Plastic Concrete," 6th International Conference of Civil Engineering, Esfehan, Iran, 5 May 2003 (in Persian).
[12] Hajnal, I., Márton, J., and Regele, Z., Construction of Diaphragm Walls, Wiley, New York, 1984, 399 pp.

[13] Xanthakos, P. P., Slurry Walls, McGraw-Hill, New York, 1979, 622 pp.

[14] Mir Ghasemi, A. A. and Haji Ghasemi, A. A., "To Investigation of Allowable Hydraulic Gradient of Plastic Concrete," 4th National Conference of Dam Construction, Tehran, Iran, 31 December 2000- 1 January 2001 (in Persian).

[15] Srinivasa Reddy, V., Jyothi Kumar, K. S., Seshagiri Rao, M. V., and Sasikala, C., "Studies on Permeability of SelfHealing Built-In Bacteria Concrete," Int. J. Recent Technol. Eng., Vol. 1, No. 6, 2013, pp. 119-125.

[16] Eslamian, F., "The Methods and Results of Young's Modulus of Plastic Concrete of Karkhe Dam Cut Off," 4th National Conference of Dam Construction, Tehran, Iran, 31 dec. 2000-1 Jan. 2001 (in Persian).

[17] ISIRI, Specification for Portland Cement, Number 389, 8th ed., Institute of Standards and Industrial Research of Iran, Tehran, Iran, 2001.

[18] ASTM D4318-05, Standard Test Methods for Liquid Limit, Plastic Limit, and Plasticity Index of Soils, ASTM International, West Conshohocken, PA, 2005, www.astm.org

[19] ICOLD, "Filling Materials for Watertight Cutoff Walls," Bulletin 51, International Committee on Large Dams, Paris, 1985.

[20] Zafari, B., Zabiholah Zadeh, A., and Sohrabi, F., "The Equipment, Methods and Results of Gotvand-Olya Dam's Cut Off Study," 2nd National Water Powerhouse Conference, Tehran, Iran, 14-15 May 2008 (in Persian).

[21] Soroush, M. and Mjtahedi, A., "An Overview of Design and Implementation of Plastic Concrete Cutoff Walls in Dams' Foundation," Proceedings of Specialized and Workshop Articles of Special Issues of Designing Dams and Its Related Organizations, Isfahan University of Technology, 5-7 October 2002, Isfahan, Iran (in Persian).

[22] Jafarzadeh, F., Dyanat Nejad, M., and Ghorbani, E., "To Study Plastic Concrete of Silouhe Dam's Cut Off-Case Study," 2nd National Conference of Concrete Technology, Tehran, Iran, 7-8 October 2010 (in Persian).

[23] DIN 1048-5, Testing Concrete; Testing of Hardened Concrete (Specimens Prepared in Mould), German Standard for Determination of Permeability of Concrete, Deutsches Institut Fur Normung e.V., Berlin, 1991.

[24] Alexander, M. and Mindess, S., Aggregates in Concrete, Modern Concrete Technology, CRC, Boca Raton, FL, 2010.

[25] Das, B. M. and Sivakugan, N., Fundamentals of Geotechnical Engineering, 5th ed., CENGAGE Learning, Boston, 2016, 767 pp.

[26] Koch, D., "Bentonites as a Basic Material for Technical Base Liners and Site Encapsulation Cut-Off Walls," Appl. Clay Sci., Vol. 21, No. 1, 2002, pp. 1-11.

[27] ASTM D2166, Standard Test Method for Unconfined Compressive Strength of Cohesive Soil, ASTM International, West Conshohocken, PA, 2005, www.astm.org

[28] ASTM C469, Standard Test Method for Static Modulus of Elasticity and Poisson's Ratio of Concrete in Compression, ASTM International, West Conshohocken, PA, 2005, www.astm.org 
JTE20160161, "Effects of Cement, Different Bentonite, and Aggregates on Plastic Concrete in Besh-Ghardash Dam, Iran," S. Kazemian and S. Ghareh, published in the Journal of Testing and Evaluation, Volume 41, No. 1, January, 2017, pp. 242-248.

The published online date incorrectly appeared as "published online December 22, 2017." The correct published online date should read "published online December 22, 2016." 